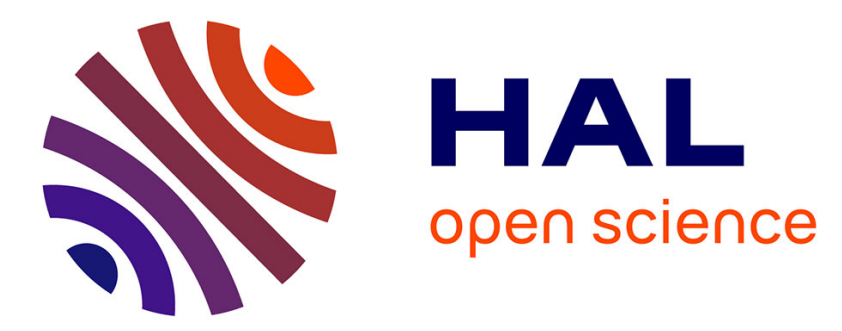

\title{
Exploring Pervasive Entertainment Games to Construct Learning Paths
}

Jannicke Hauge, Ioana Andreea Stefan, Antoniu Stefan

\section{To cite this version:}

Jannicke Hauge, Ioana Andreea Stefan, Antoniu Stefan. Exploring Pervasive Entertainment Games to Construct Learning Paths. 16th International Conference on Entertainment Computing (ICEC), Sep 2017, Tsukuba City, Japan. pp.196-201， 10.1007/978-3-319-66715-7_21 . hal-01771229

\section{HAL Id: hal-01771229 \\ https://hal.inria.fr/hal-01771229}

Submitted on 19 Apr 2018

HAL is a multi-disciplinary open access archive for the deposit and dissemination of scientific research documents, whether they are published or not. The documents may come from teaching and research institutions in France or abroad, or from public or private research centers.
L'archive ouverte pluridisciplinaire HAL, est destinée au dépôt et à la diffusion de documents scientifiques de niveau recherche, publiés ou non, émanant des établissements d'enseignement et de recherche français ou étrangers, des laboratoires publics ou privés.

\section{(c)(1)}

Distributed under a Creative Commons Attribution| 4.0 International License 


\title{
Exploring Pervasive Entertainment Games to Construct Learning Paths
}

\author{
Jannicke Madeleine Baalsrud Hauge ${ }^{1,2,3^{*}}$ Ioana Andreea Stefan ${ }^{4}$, Antoniu Stefan ${ }^{4}$,
}

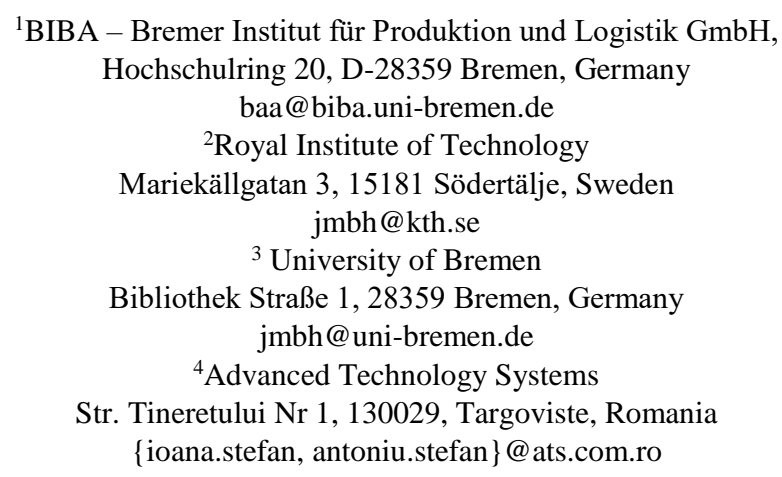

\begin{abstract}
Digital Educational Games (DEGs) aim to provide motivating, personalized play experiences that blend learning and engagement, while addressing pedagogical requirements. The ultimate challenge is to enable and stimulate knowledge acquisition by creating rich environments that employ Entertainment Games (EGs) mechanics in order to accommodate learning objectives and support skills' development. In recent years, the gap between EGs and DEGs has started to close, with studies looking not only into lessons learnt from EGs, but also into how EGs can be used in learning settings. This research analyses the possibility to integrate EGs mechanics into the pedagogical flows, in order to potentate learning. The paper further outline the design of a learning path that will be used as a unit on logistics and production means. The unit will be used for letting high school students explore functions of logistics and production (as a recruitment tool during the Open University days), as well as for the first introductionary course on production logistics.
\end{abstract}

Keywords: Pervasive mechanics, entertainment, learning, lesson path

\section{Introduction}

The massive success of Entertainment Games (EGs), such as Ingress and Pokemon GO, prove the games' capacity to act as a medium to motivate and engage individuals in various types of activities, ranging from strategizing, planning, and resource collecting to collaborating and socializing. Digital Educational Games (DEGs) aim to explore this potential in educational settings, in order to provide students with more 
attractive means to explore learning paths. In order to recruit new students to STEM subjects on activities like Open University days or to engage young museums visitors, several games have been used with great success, but often the games used for the classical course teaching, the focus on the pedagogical component has often altered the fun of DEGs or have prevented them from reaching their full engaging potential. Moreover, learning paths are individual and do not follow pre-defined scenarios, requiring in-depth levels of personalization.

The emergence of pervasive EGs has opened up new possibilities to explore userpersonalized scenarios [1], balancing randomness, individually-driven play with preestablished game goals and rules. They are able to captivate users to willingly and repeatedly play for extensive periods. Therefore, EGs offer an excellent ground for defining best practices [2] and fundament the design of DEGs that stimulate learners [3]. This paper describes a way of how EG can be integrated in an introductory class or also as a stand- alone unit to be used for recruitment settings like Open University Days.

\section{Approach for Constructing BEACONING Learning Paths}

The shift towards more flexible learning implies the adoption of new methodologies and practices. The emergence of gamification and gaming technologies offer opportunities to construct new approaches to learning, giving learners more freedom, strengthening collaboration skills, and stimulating their creative mind [4]. Pervasive Learning is such new way of learning and is defined as "learning at the speed of need through formal, informal and social learning modalities" [5]. The BEACONING project aims to take advantage of this playful pervasive learning and integrate such informal ways of learning into curricula to provide personalized learning paths. The main focus is STEM and problem-based learning [6]. The BEACONING platform will provide the users (teachers, students) diverse applications, so that the teacher with support of the integrated authoring tool and learning analytics can personalize the learning units to the specific student's needs. In order to ensure the reusability of the different learning paths, a set of templates as well as a taxonomy have been developed. The constructed learning paths have similarities to lessons plans, and will therefore be easy to use for teachers since they can easily adapt. The templates and the taxonomy are described in [6], and section 3 provides an overview on how such a path can look like.

\section{$3 \quad$ Adapted Learning Path for Understanding Industry 4.0 Applications in Production Logistics}

As described in the introduction, we have experienced that it is difficult for students to understand the technical systems and new concepts (like industry 4.0 and IoT) can support logistics operation [7, 9, 10], without experiencing how it works, specifically it they lack experience in logistics operations. This also makes it hard for future po- 
tential students to know what a study on production engineering and logistics is about. Based upon the long experience of the authors in game-based learning for the given application field, we decided to construct a new learning unit that can be used as an introduction part to a course on production logistics, as well as a single unit for workshops on open university days as the previous mentioned Open University Days. The unit is designed as a part of the small scale pilot that the BIBA will have as a part of the BEACONING project.

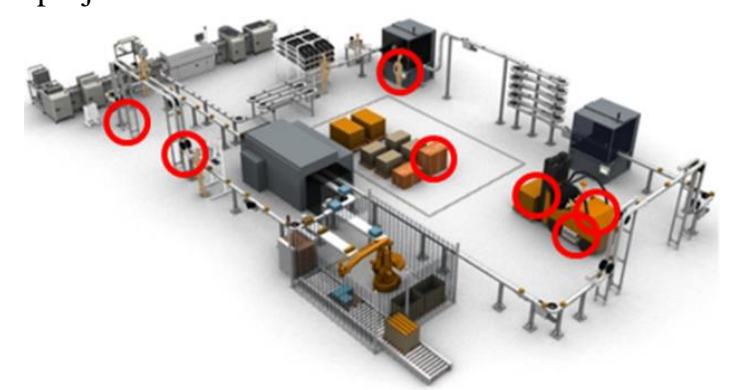

Fig. 1 Experimental Environment

Table 1 Learning Scenario on IoT in Production Logistics

A. Domain / Area / Subject: Production logistics

B. Topic: IT tools for production logistics and warehousing systems

C. Age Group / Key Stage / Year / Background

Undergraduate students starting specialization in production logistics, high school students in the phase of deciding on what to study

D. What is it about? / What's in your mind? / What's the matter?

Concepts like Industry 4.0 and Internet of Things have an increased usage with logistics and production, especially in Germany. The improved possibility to support the logistics processes by allowing access to data and information throughout the whole chain gives rise to a lot of new possibilities, but the concept itself is often difficult to grasp for students hardly knowing how logistics operations are carried out and which tools currently used. In addition, there have been a rapidly development of new technologies. This unit will let the students experience different picking technologies (picking by light, by voice, digital etiquettes etc.) as well as the stock-in and out. The lesson is problem based and the students shall experience the differences with and without technology support.

\section{E. Play - Lesson Path}

The lesson path is divided in four missions presenting basic knowledge on the underlying concepts and technologies for Industrie4.0. The lesson starts with a small (toy size) forklift able to move around move all around and to do stock-in and stock-out in a miniature warehouse. The forklift (see pict.) has sensors and actuators installed. Depending on which sensors (tilt, temperature, humidity, gravity etc.), the students will be able to carry out different operations. During the first small part the student does not get access to the data during operation, whereas these are provided in the second part. The data are collected and provided as feedback for analysis so that the students can use this experience in solving the 
next quests and challenges. This part is carried out in a safe environment in the gaming lab. The second part of the unit is organized as a treasure hunt with quests and challenges related to the equipment and tools (warehouse, large forklift, conveyer belt, picking tools) we have in different parts of the BIBA building. The students will get different challenges (i.e. on what material to store or to provide at the conveyer belt, lead times etc. relevant for production logistics tasks). With their mobile they will search for the right object to solve this tasks best (these objects are outside or in our production hall). When collected enough information on the real devices, the students will return to the lab and apply what they have learned by developing similar services equipping the miniature world with relevant sensors, actuators and define the interfaces between the PPC, ERP, etc. systems for ensuring the access to the right information. The students will test out if their application works.

Table 1 describes the learning scenario. It is based on our experiences with Ingress and Pokemon, and uses the same mechanics [11]. Table 2 describes the missions that are implemented. The game environment for mission 1 is illustrated below. Different objects will comprise different information which the students need in order to solve their tasks efficiently. For this main introductionary session is the focus on awareness raising, motivation and engagement. We therefore use game mechanics like time, competitions and exploration more than if the main learning outcome should be specific knowledge about the different system components.

Table 2 Mission Descriptions

\begin{tabular}{|c|c|c|c|}
\hline \multirow{2}{*}{\multicolumn{4}{|c|}{$\begin{array}{l}\text { Mission A: Exploring how information from information from an Ic } \\
\text { can support in- and out-stocking } \\
\text { Background: No prior knowledge on production and logistics } \\
\text { Skills: logical thinking } \\
\text { Quest 1: Discover the in- and out-stocking process in a warehouse } \\
\text { Brief overview of Ouest } 1 \text { activities. }\end{array}$}} \\
\hline & & & \\
\hline $\begin{array}{l}\text { Time Frame } \\
1 \text { hour of work in } \\
1 \text { session. }\end{array}$ & $\begin{array}{l}\text { Participants } \\
\text { The teacher } \\
\text { Their classmates }\end{array}$ & $\begin{array}{l}\text { Location(s) } \\
\text { Gaming Lab } \\
\text { BIBA hall } \\
\text { Home }\end{array}$ & $\begin{array}{l}\text { Pedagogical Re- } \\
\text { sources } \\
\text { Introductionary } \\
\text { (on line) } \\
\text { Books,Websites } \\
\text { Interactive mater }\end{array}$ \\
\hline $\begin{array}{l}\text { Evidence } \\
\text { End result, } \\
\text { Data from exer- } \\
\text { cise (i.e time used, } \\
\text { tilt and numbers } \\
\text { of errors etc). }\end{array}$ & $\begin{array}{l}\text { Rewards } \\
\text { Points to have } \\
\text { accessed/read the } \\
\text { lesson material } \\
\text { Points according } \\
\text { to performance }\end{array}$ & $\begin{array}{l}\text { Beacons } \\
\text { The beacons will } \\
\text { indicate the physi- } \\
\text { cal location of the } \\
\text { students }\end{array}$ & \\
\hline \multicolumn{4}{|c|}{$\begin{array}{l}\text { Quest } 2 \\
\text { Discover different equipment work } \\
\text { Reverse classroom style and learning by doing. }\end{array}$} \\
\hline
\end{tabular}




\begin{tabular}{|c|c|c|c|}
\hline \multicolumn{4}{|c|}{ Brief overview of Quest 2 activities. } \\
\hline $\begin{array}{l}\text { Time Frame } \\
1 \text { hour in one ses- } \\
\text { sion. }\end{array}$ & $\begin{array}{l}\text { Participants } \\
\text { The teacher } \\
\text { Their classmates }\end{array}$ & $\begin{array}{l}\text { Location(s) } \\
\text { Lab and hall } \\
\text { On their mobile }\end{array}$ & $\begin{array}{l}\text { Resources } \\
\text { Information stored } \\
\text { in the objects } \\
\text { (technical data and } \\
\text { description) } \\
\text { Videos on usage } \\
\end{array}$ \\
\hline $\begin{array}{l}\text { Evidence } \\
\text { End result (analy- } \\
\text { sis of collected } \\
\text { information) }\end{array}$ & $\begin{array}{l}\text { Rewards } \\
\text { Points awarded in } \\
\text { game are used for } \\
\text { a class/school } \\
\text { wide leaderboard }\end{array}$ & $\begin{array}{l}\text { Beacons } \\
\text { Will allow access } \\
\text { to the game within } \\
\text { building and } \\
\text { around }\end{array}$ & \\
\hline \multicolumn{4}{|c|}{$\begin{array}{l}\text { Quest } 3 \\
\text { Equip the miniature truck with different sensors and actuators and combine into } \\
\text { new services }\end{array}$} \\
\hline \multicolumn{4}{|c|}{ Brief overview of Quest 3 activities. } \\
\hline $\begin{array}{l}\text { Time Frame } \\
2 \text { hours in one } \\
\text { session. }\end{array}$ & $\begin{array}{l}\text { Participants } \\
\text { The teacher } \\
\text { The technicians } \\
\text { Their classmates }\end{array}$ & $\begin{array}{l}\text { Location(s) } \\
\text { Gaming and Fab- } \\
\text { Lab } \\
\text { On their mobile } \\
\text { On the lab PC }\end{array}$ & $\begin{array}{l}\text { Resources } \\
\text { Sensor and actua- } \\
\text { tor data } \\
\text { Description of } \\
\text { system and service } \\
\text { components (in an } \\
\text { LMS) }\end{array}$ \\
\hline $\begin{array}{l}\text { Evidence } \\
\text { End result, how } \\
\text { the different sen- } \\
\text { sors can be used to } \\
\text { provide different } \\
\text { services }\end{array}$ & $\begin{array}{l}\text { Rewards } \\
\text { Points awarded in } \\
\text { game are used for } \\
\text { a leaderboard } \\
\text { (Different points } \\
\text { for performance, } \\
\text { innovation, etc.) }\end{array}$ & $\begin{array}{l}\text { Beacons } \\
\text { Will allow access } \\
\text { to the game at } \\
\text { around the hall } \\
\text { and outside the } \\
\text { building }\end{array}$ & \\
\hline
\end{tabular}

\section{Discussion and Next Steps}

The design of the curricula and learning path, as well as of the game is now completed and we are currently adapting the game environment described in [12]. For the modding we use part of the ATMSG framework [13]. The digital part of the game is realized in Unity, and the real world data are imported into the unity scenario. (i.e. this part can be seen as a game in a game). This part is also used alone. The minigames and the overall gamification (including the treasure hunting) are integrated as a part of the overall narrative. The small scale piloting starts in autumn 2017.

\section{Acknowledgement}

The work presented herein is partially funded under the Horizon 2020 Framework Program of the European Union, BEACONING - Grant Agreement 68676 and by 
Unitatea Executiva pentru Finantarea Invatamantului Superior, a Cercetarii, Dezvoltarii si Inovarii (UEFISCDI) in Romania, Contract no. 19/ 2014 (DESiG).

\section{References}

[1] Costanza, R. et al. (2014). Simulation games that integrate research, entertainment, and learning around ecosystem services, Ecosystem Services, Volume 10, Pages 195-201. http://dx.doi.org/10.1016/j.ecoser.2014.10.001.

[2] Ham, E. (2015). Tabletop Game Design for Video Game Designers, Oxon: Focal Press.

[3] Marsh, T., Champion, E., Hlavacs, H. (2016). Special issue title: Entertainment in serious games and entertaining serious purposes, Entertainment Computing, Volume 14, Page 15. http://dx.doi.org/10.1016/j.entcom.2016.02.003.

[4] Ştefan, A. et al. (2016). Approaches to reengineering digital games. Proceedings of the ASME 2016 International Design Engineering Technical Conferences \& Computers and Information in Engineering Conference, IDETC/CIE 2016

[5] Pontefract, D. (2013). Learning by Osmosis. Retrievd from: http://www.danpontefract.com/learning-by-osmosis/

[6] BEACONING project. (2017) D3.3 Learning Environment System Specification.

[7] Baalsrud Hauge, J. et al. (2014). Deploying Serious Games for Management in Higher Education: lessons learned and good practices. In: EAI Endorsed Transactions on Serious Games

[8] Baalsrud Hauge, J. et al (2013). Study Design and Data Gathering Guide for Serious Games’ Evaluation. In: Connolly, T.M.; Hainey, T.; Boyle, E.; Baxter, G.; Moreno-Ger, P. (eds.) Psychology, Pedagogy, and Assessment in Serious Games. Advances in Game-Based Learning (AGBL) Book Series. USA: IGI Global

[9] Riedel, J.; Baalsrud Hauge, J. (2011). Evaluation of Simulation Games for Teaching Production (Engineering). In M. Cruz-Cunha, V. Varvalho, \& P. Tavares (Eds.) Computer Games as Educational and Management Tools: Uses and Approaches (pp. 263-279). Hershey, PA: Information Science Reference.

[10] Baalsrud Hauge, J. (2016). An educational framework for supporting the implementation of the Intelligent Cargo concept; International Journal Of Advanced Logistics Vol. 5 (2) pp.86-100

[11] Söbke, H. et al (2017). Prime Example Ingress Reframing the Pervasive Game Design Framework (PGDF).Int. Jour on Serious games Vol 4(2); http://dx.doi.org/10.17083/ijsg.v4i2.182

[12] Baalsrud Hauge J, et al. (2016). Analysis on Educating Mechanical Engineers Through Serious Games Using Pervasive Technologies. ASME. IDETC CIE Conference, Volume 1B: 36th Computers and Information in Engineering Conference;V01BT02A050 doi:10.1115/DETC2016-59826

[13] Carvalho, M.B. et al, (2015). "An activity theory-based model for se-rious games analysis and conceptual design", Computers \& Education, Volume 87, September 2015, Pages 166-181. 